\title{
FIELD SURVEY TO ASSESS SPREAD OF NEW ASPARAGUS DISEASES IN QUEENSLAND
}

\author{
L-H CHEAH ${ }^{1}$, C.M. HORLOCK ${ }^{2}$ and R.D. DAVIS ${ }^{2}$ \\ ${ }^{1}$ Crop \& Food Research, Private Bag 11600, Palmerston North, New Zealand \\ ${ }^{2}$ DPI, Indooroopilly Research Centre, Qld 4068, Australia \\ Corresponding author: cheahl@crop.cri.nz
}

\begin{abstract}
Asparagus (Asparagus officinalis) crops on eight Queensland properties were surveyed for the presence of asparagus rust (caused by Puccinia asparagi), phomopsis stem blight (caused by Phomopsis asparagi) and asparagus anthracnose (caused by Colletotrichum gloeosporioides) in November 2002. All properties surveyed had a low incidence of rust disease. Most rust developed on plants two weeks after spear emergence. No symptoms of phomopsis stem blight or anthracnose were found in the Mundubbera and Beerburrum regions. Anthracnose was found only in Mareeba (northern Queensland). The incidence of phomopsis stem blight was found to be high on one property in the Warwick region. Examination of diseased plants showed that the respective pathogens were associated with the symptoms. Drought was a major problem for growers and we observed that crops with an appropriate fertiliser and irrigation regime showed increased plant growth and less disease. Crops with irrigation alone also showed better growth and less disease than those without irrigation. Our observations suggest that an appropriate irrigation and fertiliser regime that promotes plant growth and health will lessen the likelihood of infection by these diseases. However, more research is required to confirm this.

Keywords: Asparagus anthracnose, Colletotrichum gloeosporioides, Phomopsis asparagi, Puccinia asparagi, survey.
\end{abstract}

\section{INTRODUCTION}

Three new diseases, asparagus rust, Phomopsis stem blight and asparagus anthracnose, were first detected on asparagus in Queensland, Australia, in 2000 (Davis 2001a, 2001b). Both asparagus rust and stem blight caused significant crop losses. None of these diseases had previously been recorded on asparagus in either Australia or New Zealand.

Symptoms of asparagus rust, phomopsis stem blight and asparagus anthracnose have been described (Cheah \& Davis 2002). Rust decreases plant vigour and reduces the quality of asparagus spears. Severely diseased plants may prematurely senesce and die during summer. Phomopsis stem blight causes fern defoliation and loss of production (Cheah \& Davis 2002). Infected stems turn yellow, senesce and die rapidly when the lesions girdle the stem bases. The potential importance of asparagus anthracnose remains unclear. These three diseases are likely to spread to other states in Australia and to New Zealand; asparagus rust is the one most likely to spread widely because of its airborne urediniospores. Asparagus rust is therefore very likely to occur in New Zealand within the next few years (NZ Asparagus Council 2001).

Growers from both countries have expressed concern about the damaging effects of these diseases and have requested an investigation to determine the extent and severity of infections in asparagus crops in Queensland since the first record of the diseases. This paper reports the results of a field survey to assess disease spread, and discusses strategies under consideration in Queensland to minimise infection by rust, phomopsis and anthracnose. 


\section{MATERIALS AND METHODS}

Eight properties (four in Mundubbera (north-west of Brisbane), one in Beerburrum (north-west of Brisbane), two in Warwick (west of Brisbane) and one in Mareeba (northern Queensland)) of major asparagus growers in Queensland were surveyed. Field surveys were carried out on 18-20 November 2002 by walking between rows of asparagus and observing fern growth and plant stems for symptoms of the three diseases. Surveyed sites were chosen based on growers' information about the occurrence of the diseases. All crops were in the fern stage of growth. Four rows of about $70 \mathrm{~m}$ long (about 600 plants) were surveyed on each property. Disease incidence was recorded as the percentage of plants inspected that were diseased. The survey focused on cv. UC157, which is the main cultivar grown in Queensland. Any plants with possible disease symptoms were collected and returned to the laboratory for identification.

In the laboratory, the collected samples were examined microscopically before being lodged in a herbarium at the Department of Primary Industries, Indooroopilly. Some of the samples were also surface-sterilised and plated on to potato-dextrose agar to isolate causative fungi.

\section{RESULTS}

Asparagus rust was found on all properties surveyed, but the incidence was low to moderate (Table 1). Most rust developed on plants two weeks after spear emergence. Phomopsis stem blight was found only in the Warwick region and the incidence was high on one property. Anthracnose was found only on one property in northern Queensland (Mareeba).

The fungi that grew on cultures were examined microscopically and were found to be the pathogens expected to be associated with the symptoms.

TABLE 1: Incidence (estimated proportion of plants affected) of rust, phomopsis stem blight and anthracnose on asparagus (cv. UC157) crops in Queensland.

\begin{tabular}{llccc}
\hline Property & Location & Rust & Phomopsis & Anthracnose \\
\hline 1 & Mundubbera & $<1 \%$ & nil & nil \\
2 & Mundubbera & $<1 \%$ & nil & nil \\
3 & Mundubbera & $<1 \%$ & nil & nil \\
4 & Mundubbera & $<1 \%$ & nil & nil \\
5 & Beerburrum & $<1 \%$ & nil & nil \\
6 & Warwick & $20 \%$ & $60 \%$ & nil \\
7 & Warwick & $<1 \%$ & $<1 \%$ & nil \\
8 & Mareeba & $<1 \%$ & nil & $<1 \%$ \\
\hline
\end{tabular}

Drought was a major problem for growers, causing plant stress and greater susceptibility of crops to infection. We observed that crops that had an appropriate fertiliser and irrigation regime had increased plant growth and less disease within the same property. Even with irrigation alone, plants tended to be healthier (greener) and to show better growth and less disease than those without irrigation.

\section{DISCUSSION}

The survey showed that in the 30 months since rust was first found on a single property in south Queensland on cv. UC157 (Davis 2001b), it had spread to northern Queensland. Clearly, property quarantine measures and crop destruction failed to contain the pathogen and the disease is now endemic throughout asparagus-producing areas in south Queensland. Phomopsis stem blight is a serious disease throughout tropical and sub-tropical asparagus areas in Asia and SE Asia (Liu \& Hwang 1988; Xu et al. 1996; Sonoda et al. 1997), but before 2001 had never been recorded in Australia (Davis 2001a). This disease is currently more restricted in Queensland than rust. Neither rust, phomopsis 
stem blight nor anthracnose has been found in other regions of Australia. The incidence of these three diseases was low compared to the previous season (Davis 2002), possibly due to the more severe frosts that occurred during the winter of 2002. Drought was also a major problem during the summer of 2002. Urediniospores require moisture for infection, and severe outbreaks of rust are dependent on wet weather (Elmer et al. 1996). Conidia of Phomopsis asparagi and Colletotrichum gloeosporioides also require wet conditions for spread and host infection (Davis 2002). Under dry, hot weather conditions, pathogen spread and infection are slower and limited, although plants may be stressed by drought.

Our field survey suggested that crops with both appropriate fertiliser and irrigation regimes had increased plant growth and less disease. Crops with irrigation alone also tended to be healthier and have less disease than those without irrigation.

On the basis of limited information about these new diseases in Australia and the results of our survey, we suggest that applying an appropriate irrigation and fertiliser regime to promote plant growth and health is likely to minimise infection. However, further study should be carried out to investigate the benefit of irrigation and fertiliser in reducing infection. The integrated use of resistant cultivars, sanitation practices, irrigation and timely application of fungicides is also recommended for the management of these diseases.

\section{ACKNOWLEDGEMENTS}

We thank Horticulture Australia Limited; Queensland growers; the Department of Natural Resources and Environment, Victoria; the Australia Asparagus Council; Sunraysia Asparagus Growers; and the NZ Asparagus Council for funding this project. Thanks also to Gisele Irvine, Janine Clark, Kathy Grice and Sally-Ann Henderson for assistance.

\section{REFERENCES}

Cheah, L-H.; Davis, R.D. 2002: New diseases of asparagus - a threat to New Zealand's biosecurity. N.Z. Plant Prot. 55: 49-52.

Davis, R.D. 2001a: Asparagus stem blight recorded in Australia. Aust. Plant Path. 30: 181-182.

Davis, R.D. 2001b: Asparagus rust recorded in Australia. Aust. Plant Path. 30:183-184.

Davis, R.D. 2002: Management of three newly recorded asparagus diseases in Quensland will require adoption of new production strategies. Proc. 10 $0^{\text {th }}$ Int. Asparagus Symposium (Japan): 365-371.

Elmer, W.H.; Johnson, D.A.; Mink, G.I. 1996: Epidemiology and management of the diseases causal to asparagus decline. Plant Disease 80: 117-125.

Liu, T.M.E.; Hwang, J.S. 1988: Survival and overwintering of Phoma asparagi. Pl. Prot. Bull. Taiwan 30: 24-30.

NZ Asparagus Council 2001: The threat from asparagus rust. Spearhead 11(3): 3-8.

Sonoda, T.; Uragami, A.; Kaji, K. 1997: Evaluation of Asparagus officinalis cultivars for resistance to stem blight by using a novel inoculation method. HortScience 32: 1085-1086.

Xu, H.L.; Peng, M.S.; Feng, X.T. 1996: Asparagus production in China. Proc. VIII Int. Asparagus Symposium Acta Hort.: 41-44. 